\title{
Synthesis, spectral correlations and antimicrobial activities of 2-pyrimidine Schiff's bases
}

\author{
R. Senbagam ${ }^{a}$, M. Rajarajan ${ }^{a}$, R. Vijayakumar ${ }^{a}$, V. Manikandan $^{a}$, S. Balaji ${ }^{\mathrm{a}}$, \\ G. Vanangamudi ${ }^{\mathrm{a},}$, G. Thirunarayana,
}

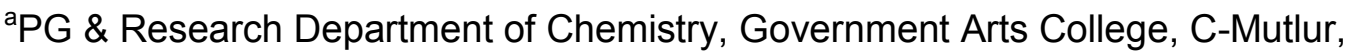
Chidambaram- 608 102, India.

bepartment of Chemistry, Annamalai University, Annamalainagar-608 002, India.

*E-mail address: drgvsibi@gmail.com

\begin{abstract}
Keywords: Synthesis, 2-pyrimidine Schiff's bases, UV, IR and NMR spectra, regression analysis and antimicrobial activities.
\end{abstract}

ABSTRACT. In the present study, a series of substituted $(E)$ - $N$-benzylidene-2-aminopyrimidine compounds have been synthesized by condensation reaction with 2 -aminopyrimidine and meta- and para- substituted benzaldehydes. These synthesized Schiff's base compounds are confirmed by their physical constants, UV, IR and NMR spectral data. All the observed UV absorption maximum $\lambda_{\max }(\mathrm{nm})$, IR frequencies $v \mathrm{C}=\mathrm{N}\left(\mathrm{cm}^{-1}\right)$, NMR $\delta(\mathrm{ppm})$ of $\mathrm{C}-\mathrm{H} \& \mathrm{C}=\mathrm{N}$ chemical shifts have been correlated with Hammett substituent constants and $F$ and $R$ parameters using single and multi-linear regression analyses in order to study the effect of substituents on these spectral data has been studied. The antimicrobial activities of all the synthesized Schiff's base compounds have been studied using Bauer-Kirby disc diffusion method.

\section{INTRODUCTION}

Schiff's bases are an important class of organic compounds possessing biological activities and structural significance. It has been proved that the incorporation of this molecule into the biologically active azomethine linkage $(-\mathrm{CH}=\mathrm{N}-)$ produces compounds with high pharmacological activity [1]. Schiff's bases are represented by the general formula $\mathrm{RCH}=\mathrm{NR}$ ' where $>\mathrm{C}=\mathrm{N}$ is the azomethine group[2]. The colour of the Schiff's bases is due to the presence of this azomethine $(>\mathrm{C}=\mathrm{N})$ linkage and can vary by introducing other auxochromic groups. When functional groups, such as $-\mathrm{OH},-\mathrm{SH},-\mathrm{COOH}$ are present in these ligands in suitably tailored positions, they enable them to be powerful chelating, biological and analytical reagents. On this basis of such groups present, the Schiff's bases may be di, tri, tetra or polydentate in nature. Compounds containing azomethine group are basic in nature, as $\mathrm{N}$ atom of this group has a lone pare of electrons and the double bond has electron donating character. Schiff's bases displayed the phenomenon of tautomeris[3], thermochromy and photochromy[4] and geometrical isomerism[5]. They possess both types of hydrogen bonding i.e. intra-molecular as well as inter-molecular [6]. Schiff's bases are widely studied and used in the fields of organic synthesis and metal ion complexation [7] for a number of reasons: their physiological and pharmacological activities [8] their use in ionselective electrodes [9] in the determination of heavy metals ions in environmental samples [10] and in the extraction of metals ions [11,12] and their many catalytic applications (e.g. for epoxidation of olefins, alkene cyclopropanation [13,14] trimethylsilylcyanation of ketones [15] asymmetric oxidation of methyl phenyl sulfide enantioselective epoxidation of silylenol [16] and ring-opening polymerization of lactide [17]. In recent years, correlation analysis has been applied by chemists for solving the effect of substituents on Schiff's bases through spectral data. Literature survey shows that there is no information available regarding the study of UV, IR and NMR spectral correlation and antimicrobial activities of substituted $(E)-N$-benzylidene-2-aminopyrimidine compounds. Hence the authors have taken efforts for synthesizing substituted $(E)$ - $N$-benzylidene-2aminopyrimidine compounds and studying the effect of substituents through the spectral data and their antimicrobial activities. 


\section{EXPERIMENTAL}

\subsection{General}

All the chemicals used have been purchased from Sigma-Aldrich and E-Merck chemical companies. Melting points of all of substituted $(E)$ - $N$-benzylidene-2-aminopyrimidine compounds have been observed in open glass capillaries on a Mettler FP51 melting point apparatus and are uncorrected. The UV spectra of all synthesized $(E)$ - $N$-benzylidene-2-aminopyrimidine compounds have been recorded using SHIMADZU-1650 SPECTROMETER in spectral grade methanol. IR spectra $\left(\mathrm{KBr}, 4000-400 \mathrm{~cm}^{-1}\right.$ ) have been recorded on AVATAR-300 Fourier transform spectrophotometer. The NMR spectra of all the substituted $(E)$ - $N$-benzylidene-2-aminopyrimidine compounds have been recorded in BRUKER 400 spectrometer operating at $400 \mathrm{MHz}$ for ${ }^{1} \mathrm{H} \mathrm{NMR}$ spectra and $100 \mathrm{MHz}$ for ${ }^{13} \mathrm{C}$ NMR spectra in $\mathrm{CDCl}_{3}$ solvent using TMS as internal standard.

\subsection{Synthesis of substituted $(E)$ - $N$-benzylidene-2-aminopyrimidine compounds}

Equimolar quantities of 2-aminopyrimidine $(0.01 \mathrm{~mol})$, substituted benzaldehyde $(0.01 \mathrm{~mol})$ and $0.5 \mathrm{ml}$ acetic acid were refluxed for $3 \mathrm{~h}$ with $20 \mathrm{~mL}$ of absolute ethanol $[18,19]$. The completion of the reaction was monitored by TLC continuously. The resultant mixture was cooled at room temperature. Then the obtained precipitate was filtered and washed several times with cold water. A yellowish solid was obtained as the product. This crude product was recrystallized from ethanol to get glittering colorless solid, and their melting points were been observed. The general reaction is shown in Scheme 1.<smiles>Nc1ncccn1</smiles><smiles>[X]c1cccc(C=O)c1</smiles>

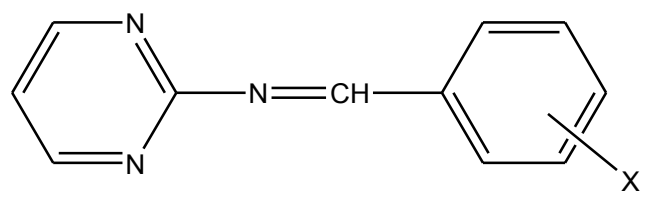

Scheme 1. $\mathrm{X}=\mathrm{H}, 3-\mathrm{Br}, 4-\mathrm{Br}, 3-\mathrm{Cl}, 4-\mathrm{Cl}, 4-\mathrm{F}, 4-\mathrm{CH}_{3}, 4-\mathrm{OCH}_{3}, 3-\mathrm{NO}_{2}, 4-\mathrm{NO}_{2}$

All the compounds synthesized in the present investigation have been identified by their physical constants, UV, IR and NMR spectral data and are shown in Table 1. The spectral data of all the synthesized substituted $(E)$ - $N$-benzylidene-2-aminopyrimidine compounds have been correlated with Hammett substituent constants and $F$ and $R$ parameter and are shown in Table 2.

Table 1. The UV, IR and NMR spectroscopic data of substituted (E)- $N$-benzylidene-2aminopyrimidines

\begin{tabular}{|l|l|l|l|l|l|l|l|l|}
\hline Entry & $\mathrm{X}$ & $\mathrm{M} . \mathrm{F}$. & $\mathrm{M} . \mathrm{W}$. & $\mathrm{M} . \mathrm{p} .\left({ }^{\circ} \mathrm{C}\right)$ & $\begin{array}{l}\lambda_{\max } \\
(\mathrm{nm})\end{array}$ & $\begin{array}{l}v \mathrm{C}=\mathrm{N} \\
\left(\mathrm{cm}^{-1}\right)\end{array}$ & $\begin{array}{l}\delta^{1} \mathrm{H} \\
\mathrm{CH}=\mathrm{N} \\
(\mathrm{ppm})\end{array}$ & $\begin{array}{l}\delta^{13} \mathrm{C} \\
\mathrm{C}=\mathrm{N} \\
(\mathrm{ppm})\end{array}$ \\
\hline 1 & $\mathrm{H}$ & $\mathrm{C}_{11} \mathrm{H}_{9} \mathrm{~N}_{3}$ & 183.21 & $\begin{array}{l}75-76 \\
(76)[20]\end{array}$ & 291.50 & 1645.28 & 8.564 & 163.18 \\
\hline 2 & $3-\mathrm{Br}$ & $\mathrm{C}_{11} \mathrm{H}_{8} \mathrm{BrN}_{3}$ & 262.11 & $117-118$ & 277.50 & 1643.42 & 8.668 & 158.04 \\
\hline 3 & $4-\mathrm{Br}$ & $\mathrm{C}_{11} \mathrm{H}_{8} \mathrm{BrN}_{3}$ & 262.11 & $121-122$ & 291.50 & 1643.28 & 8.374 & 156.94 \\
\hline 4 & $3-\mathrm{Cl}$ & $\mathrm{C}_{11} \mathrm{H}_{8} \mathrm{ClN}_{3}$ & 217.65 & $91-92$ & 287.00 & 1645.35 & 8.377 & 162.43 \\
\hline 5 & $4-\mathrm{Cl}$ & $\mathrm{C}_{11} \mathrm{H}_{8} \mathrm{ClN}_{3}$ & 217.65 & $\begin{array}{l}46-47 \\
(45-46)[21]\end{array}$ & 292.00 & 1647.28 & 8.664 & 163.55 \\
\hline 6 & $4-\mathrm{F}$ & $\mathrm{C}_{11} \mathrm{H}_{8} \mathrm{FN}_{3}$ & 201.20 & $96-97$ & 292.50 & 1653.07 & 8.610 & 163.03 \\
\hline 7 & $4-\mathrm{CH}_{3}$ & $\mathrm{C}_{12} \mathrm{H}_{11} \mathrm{~N}_{3}$ & 197.24 & $159-160$ & 292.50 & 1647.28 & 8.527 & 163.15 \\
\hline 8 & $4-\mathrm{OCH}_{3}$ & $\mathrm{C}_{12} \mathrm{H}_{11} \mathrm{~N}_{3} \mathrm{O}$ & 213.24 & $\begin{array}{l}173-174 \\
(175)[21]\end{array}$ & 291.50 & 1647.28 & 8.563 & 163.21 \\
\hline 9 & $3-\mathrm{NO}_{2}$ & $\mathrm{C}_{11} \mathrm{H}_{8} \mathrm{~N}_{4} \mathrm{O}_{2}$ & 228.21 & $183-184$ & 267.50 & 1654.03 & 8.748 & 158.35 \\
\hline 10 & $4-\mathrm{NO}_{2}$ & $\mathrm{C}_{11} \mathrm{H}_{8} \mathrm{~N}_{4} \mathrm{O}_{2}$ & 228.21 & $167-168$ & 269.00 & 1664.64 & 8.569 & 160.60 \\
\hline
\end{tabular}


Table 2. Results of statistical analyses of $U V \lambda_{\max }(\mathrm{nm}), v \mathrm{C}=\mathrm{N}\left(\mathrm{cm}^{-1}\right) \mathrm{IR}, \mathrm{NMR} \delta^{1} \mathrm{H}(\mathrm{ppm}) \mathrm{CH}=\mathrm{N}$ and $\delta^{13} \mathrm{C}(\mathrm{ppm}) \mathrm{C}=\mathrm{N}$ of substituted $(E)-N$-benzylidene-2-aminopyrimidine compounds with Hammett substituent constants $\sigma, \sigma^{+}, \sigma_{\mathrm{I}}, \sigma_{\mathrm{R}}$ and $F$ and $R$ parameters

\begin{tabular}{|c|c|c|c|c|c|c|c|}
\hline Frequency & Constants & $\mathrm{r}$ & I & $\rho$ & $\mathrm{s}$ & $\mathrm{n}$ & Correlated derivatives \\
\hline \multirow[t]{6}{*}{$\lambda_{\max (\mathrm{nm})}$} & $\sigma$ & 0.900 & 291.11 & -25.026 & 5.176 & 7 & $\begin{array}{l}\mathrm{H}, 4-\mathrm{Br}, 3-\mathrm{Cl}, 4-\mathrm{Cl}, 4-\mathrm{F}, 4-\mathrm{CH}_{3}, 4- \\
\mathrm{OCH}_{3}\end{array}$ \\
\hline & $\sigma^{+}$ & 0.901 & 287.88 & -15.635 & 7.076 & 7 & $\begin{array}{l}\mathrm{H}, 4-\mathrm{Br}, 3-\mathrm{Cl}, 4-\mathrm{Cl}, 4-\mathrm{F}, 4-\mathrm{CH}_{3}, 4- \\
\mathrm{OCH}_{3}\end{array}$ \\
\hline & $\sigma_{I}$ & 0.906 & 295.29 & -25.549 & 8.389 & 7 & $\begin{array}{l}\mathrm{H}, 4-\mathrm{Br}, 3-\mathrm{Cl}, 4-\mathrm{Cl}, 4-\mathrm{F}, 4-\mathrm{CH}_{3}, 4- \\
\mathrm{OCH}_{3}\end{array}$ \\
\hline & $\sigma_{\mathrm{R}}$ & 0.907 & 280.53 & -34.474 & 7.511 & 7 & $\begin{array}{l}\mathrm{H}, 4-\mathrm{Br}, 3-\mathrm{Cl}, 4-\mathrm{Cl}, 4-\mathrm{F}, 4-\mathrm{CH}_{3}, 4- \\
\mathrm{OCH}_{3}\end{array}$ \\
\hline & $\mathrm{F}$ & 0.905 & 293.81 & -20.975 & 9.088 & 7 & $\begin{array}{l}\mathrm{H}, 4-\mathrm{Br}, 3-\mathrm{Cl}, 4-\mathrm{Cl}, 4-\mathrm{F}, 4-\mathrm{CH}_{3}, 4- \\
\mathrm{OCH}_{3}\end{array}$ \\
\hline & $\mathrm{R}$ & 0.900 & 280.09 & -27.126 & 7.961 & 7 & $\begin{array}{l}\mathrm{H}, 4-\mathrm{Br}, 3-\mathrm{Cl}, 4-\mathrm{Cl}, 4-\mathrm{F}, 4-\mathrm{CH}_{3}, 4- \\
\mathrm{OCH}_{3}\end{array}$ \\
\hline \multirow[t]{6}{*}{$v \mathrm{C}=\mathrm{N}\left(\mathrm{cm}^{-1}\right)$} & $\sigma$ & 0.815 & 1647.09 & 9.823 & 5.748 & 10 & $\begin{array}{l}\mathrm{H}, 3-\mathrm{Br}, 4-\mathrm{Br}, 3-\mathrm{Cl}, 4-\mathrm{Cl}, 4-\mathrm{F}, 4- \\
\mathrm{CH}_{3}, 4-\mathrm{OCH}_{3}, 3-\mathrm{NO}_{2}, 4-\mathrm{NO}_{2}\end{array}$ \\
\hline & $\sigma^{+}$ & 0.805 & 1648.52 & 5.153 & 6.287 & 10 & $\begin{array}{l}\mathrm{H}, 3-\mathrm{Br}, 4-\mathrm{Br}, 3-\mathrm{Cl}, 4-\mathrm{Cl}, 4-\mathrm{F}, 4- \\
\mathrm{CH}_{3}, 4-\mathrm{OCH}_{3}, 3-\mathrm{NO}_{2}, 4-\mathrm{NO}_{2}\end{array}$ \\
\hline & $\sigma_{\mathrm{I}}$ & 0.835 & 1644.99 & 11.165 & 6.177 & 10 & $\begin{array}{l}\mathrm{H}, 3-\mathrm{Br}, 4-\mathrm{Br}, 3-\mathrm{Cl}, 4-\mathrm{Cl}, 4-\mathrm{F}, 4- \\
\mathrm{CH}_{3}, 4-\mathrm{OCH}_{3}, 3-\mathrm{NO}_{2}, 4-\mathrm{NO}_{2}\end{array}$ \\
\hline & $\sigma_{\mathrm{R}}$ & 0.901 & 1651.25 & 13.601 & 6.125 & 8 & $\begin{array}{l}\mathrm{H}, 3-\mathrm{Br}, 4-\mathrm{Br}, 3-\mathrm{Cl}, 4-\mathrm{Cl} \\
\text { 4- } \mathrm{CH}_{3}, 3-\mathrm{NO}_{2}, 4-\mathrm{NO}_{2}\end{array}$ \\
\hline & $\mathrm{F}$ & 0.842 & 1644.37 & 12.302 & 5.972 & 10 & $\begin{array}{l}\mathrm{H}, 3-\mathrm{Br}, 4-\mathrm{Br}, 3-\mathrm{Cl}, 4-\mathrm{Cl}, 4-\mathrm{F}, 4- \\
\mathrm{CH}_{3}, 4-\mathrm{OCH}_{3}, 3-\mathrm{NO}_{2}, 4-\mathrm{NO}_{2}\end{array}$ \\
\hline & $\mathrm{R}$ & 0.905 & 1651.39 & 10.513 & 6.235 & 8 & $\begin{array}{l}\mathrm{H}, 3-\mathrm{Br}, 4-\mathrm{Br}, 3-\mathrm{Cl}, 4-\mathrm{Cl} \\
4-\mathrm{CH}_{3}, 3-\mathrm{NO}_{2}, 4-\mathrm{NO}_{2}\end{array}$ \\
\hline \multirow[t]{6}{*}{$\delta \mathrm{CH}=\mathrm{N}(\mathrm{ppm})$} & $\sigma$ & 0.965 & 8.288 & 0.246 & 0.121 & 7 & $\begin{array}{l}\mathrm{H}, 3-\mathrm{Br}, 4-\mathrm{Cl}, 4-\mathrm{F}, 4-\mathrm{CH}_{3}, \\
4-\mathrm{OCH}_{3}, 3-\mathrm{NO}_{2}\end{array}$ \\
\hline & $\sigma^{+}$ & 0.984 & 8.321 & 0.144 & 0.139 & 7 & $\begin{array}{l}\mathrm{H}, 3-\mathrm{Br}, 4-\mathrm{Cl}, 4-\mathrm{F}, 4-\mathrm{CH}_{3}, \\
4-\mathrm{OCH}_{3}, 3-\mathrm{NO}_{2}\end{array}$ \\
\hline & $\sigma_{I}$ & 0.944 & 8.243 & 0.260 & 0.136 & 7 & $\begin{array}{l}\mathrm{H}, 3-\mathrm{Br}, 4-\mathrm{Cl}, 4-\mathrm{F}, 4-\mathrm{CH}_{3}, \\
4-\mathrm{OCH}_{3}, 3-\mathrm{NO}_{2}\end{array}$ \\
\hline & $\sigma_{R}$ & 0.825 & 8.402 & 0.409 & 0.123 & 10 & $\begin{array}{l}\mathrm{H}, 3-\mathrm{Br}, 4-\mathrm{Br}, 3-\mathrm{Cl}, 4-\mathrm{Cl}, 4-\mathrm{F}, 4- \\
\mathrm{CH}_{3}, 4-\mathrm{OCH}_{3}, 3-\mathrm{NO}_{2}, 4-\mathrm{NO}_{2}\end{array}$ \\
\hline & $\mathrm{F}$ & 0.795 & 8.251 & 0.232 & 0.139 & 10 & $\begin{array}{l}\mathrm{H}, 3-\mathrm{Br}, 4-\mathrm{Br}, 3-\mathrm{Cl}, 4-\mathrm{Cl}, 4-\mathrm{F}, 4- \\
\mathrm{CH}_{3}, 4-\mathrm{OCH}_{3}, 3-\mathrm{NO}_{2}, 4-\mathrm{NO}_{2}\end{array}$ \\
\hline & $\mathrm{R}$ & 0.844 & 8.408 & 0.327 & 0.126 & 10 & $\begin{array}{l}\mathrm{H}, 3-\mathrm{Br}, 4-\mathrm{Br}, 3-\mathrm{Cl}, 4-\mathrm{Cl}, 4-\mathrm{F}, 4- \\
\mathrm{CH}_{3}, 4-\mathrm{OCH}_{3}, 3-\mathrm{NO}_{2}, 4-\mathrm{NO}_{2}\end{array}$ \\
\hline \multirow[t]{6}{*}{$\delta \mathrm{C}=\mathrm{N}(\mathrm{ppm})$} & $\sigma$ & 0.904 & 162.19 & -2.999 & 2.524 & 7 & $\begin{array}{l}\mathrm{H}, 3-\mathrm{Cl}, 4-\mathrm{Cl}, 4-\mathrm{F}, 4-\mathrm{CH}_{3}, \\
4-\mathrm{OCH}_{3}, 4-\mathrm{NO}_{2}\end{array}$ \\
\hline & $\sigma^{+}$ & 0.905 & 161.95 & -2.718 & 2.386 & 7 & $\begin{array}{l}\mathrm{H}, 3-\mathrm{Cl}, 4-\mathrm{Cl}, 4-\mathrm{F}, 4-\mathrm{CH}_{3} \\
4-\mathrm{OCH}_{3}, 4-\mathrm{NO}_{2}\end{array}$ \\
\hline & $\sigma_{\mathrm{I}}$ & 0.829 & 163.11 & -4.118 & 2.548 & 10 & $\begin{array}{l}\mathrm{H}, 3-\mathrm{Br}, 4-\mathrm{Br}, 3-\mathrm{Cl}, 4-\mathrm{Cl}, 4-\mathrm{F}, 4- \\
\mathrm{CH}_{3}, 4-\mathrm{OCH}_{3}, 3-\mathrm{NO}_{2}, 4-\mathrm{NO}_{2}\end{array}$ \\
\hline & $\sigma_{R}$ & 0.890 & 161.06 & -3.153 & 2.672 & 10 & $\begin{array}{l}\mathrm{H}, 3-\mathrm{Br}, 4-\mathrm{Br}, 3-\mathrm{Cl}, 4-\mathrm{Cl}, 4-\mathrm{F}, 4- \\
\mathrm{CH}_{3}, 4-\mathrm{OCH}_{3}, 3-\mathrm{NO}_{2}, 4-\mathrm{NO}_{2}\end{array}$ \\
\hline & $\mathrm{F}$ & 0.826 & 162.73 & -3.025 & 4.639 & 10 & $\begin{array}{l}\mathrm{H}, 3-\mathrm{Br}, 4-\mathrm{Br}, 3-\mathrm{Cl}, 4-\mathrm{Cl}, 4-\mathrm{F}, 4- \\
\mathrm{CH}_{3}, 4-\mathrm{OCH}_{3}, 3-\mathrm{NO}_{2}, 4-\mathrm{NO}_{2}\end{array}$ \\
\hline & $\mathrm{R}$ & 0.861 & 161.07 & -2.182 & 4.700 & 10 & $\begin{array}{l}\mathrm{H}, 3-\mathrm{Br}, 4-\mathrm{Br}, 3-\mathrm{Cl}, 4-\mathrm{Cl}, 4-\mathrm{F} \\
\text { 4-CH} \\
-\mathrm{CH}_{3}, 4-\mathrm{OCH}_{3}, 3-\mathrm{NO}_{2}, 4-\mathrm{NO}_{2}\end{array}$ \\
\hline
\end{tabular}




\section{RESULTS AND DISSCUSION}

\subsection{UV-Visible spectral correlations}

The assigned UV absorption maximum $\lambda_{\max }(\mathrm{nm})$ values of all the substituted (E)- $N$-benzylidene-2-amino pyrimidine compounds are presented in Table 1. These UV absorption maximum $\lambda_{\max }(\mathrm{nm})$ values are correlated with different Hammett substituent constants and $F$ $\& R$ parameters using single and multi-linear regression analyses according to the approach of John Shorter [22]. Hammett equation employed, for the correlation analysis, involving the UV absorption maximum is shown in equation (1).

$$
\lambda=\rho \sigma+\lambda_{0}
$$

where $\lambda_{0}$ is the absorption maximum of the parent member of this series.

The results of statistical analyses [18, 23-29] is shown in Table 2. The assigned UV absorption maximum $\lambda_{\max }(\mathrm{nm})$ values of all the substituted $(E)$ - $N$-benzylidene-2-amino pyrimidine compounds, except those with 3-Br, 3- $\mathrm{NO}_{2}$ and $4-\mathrm{NO}_{2}$ substituents have shown satisfactory correlations with all the Hammett substituent constants namely, $\sigma(\mathrm{r}=0.900)$, $\sigma^{+}(\mathrm{r}=0.901), \sigma_{\mathrm{I}}(\mathrm{r}=0.906), \quad \sigma_{\mathrm{R}}(\mathrm{r}=0.907)$ and Swain-Lupton's[30] $F(\mathrm{r}=0.905)$ and $R(\mathrm{r}=0.900)$ parameters. When these substituents that have been given exception are included in regression they reduce the correlations considerably. All the correlations with Hammett constants and $F$ and $R$ parameters have shown negative $\rho$ values. This indicates the operation of reverse substituent effect with respect to UV absorption maximum $\lambda_{\max }(\mathrm{nm})$ values of all the substituted $(E)$ - $N$-benzylidene-2-aminopyrimidine compounds.

All the correlations have shown satisfactory correlation co-efficient values individually. The multi-regression analyses with Hammett constants $\sigma_{\mathrm{I}} \& \sigma_{\mathrm{R}}$ and Swain-Lupton's[30] $F \& R$ parameters have also shown satisfactory correlations as shown in the following equations (2) and (3).

$$
\begin{aligned}
\lambda_{\max }(\mathrm{nm})= & 289.68( \pm 3.647)-22.119( \pm 3.311) \sigma_{\mathrm{I}}-31.116( \pm 4.580) \sigma_{\mathrm{R}} \\
& (R=0.988, \mathrm{n}=10, \mathrm{P}>95 \%) \\
\lambda_{\max }(\mathrm{nm})= & 288.921( \pm 3.841)-22.03( \pm 2.609) F-27.995( \pm 2.761) R \\
& (R=0.986, \mathrm{n}=10, \mathrm{P}>95 \%)
\end{aligned}
$$

\subsection{IR Spectral correlation}

The assigned infrared stretching frequency $v \mathrm{C}=\mathrm{N}\left(\mathrm{cm}^{-1}\right)$ values of all the substituted $(E)-N$ benzylidene 2-amino pyrimidine compounds are presented in Table 1. These infrared stretching frequency values are correlated with different Hammett substituent constants and parameters using single and multi-linear regression analyses according to the approach of Jaffe [31].

The structure parameter correlation involving group frequencies, the employed Hammett equation is shown in equation (4).

$$
v=\rho \sigma+v_{0}
$$

where $v_{0}$ is the frequency of the parent member of this series

The results of the statistical analyses[18, 23-29] are presented in Table 2. From this table, it is evident that the infrared that the infrared stretching frequency $v \mathrm{C}=\mathrm{N}\left(\mathrm{cm}^{-1}\right)$ values of all the substituted $(E)$ - $N$-benzylidene 2-amino pyrimidine compounds, except those with 4 -F and $4-\mathrm{OCH}_{3}$ substituents have shown satisfactory correlations with Hammett constant $\sigma_{R}(\mathrm{r}=0.901)$ and Swain-Lupton's $R \quad(\mathrm{r}=0.905)$ parameter. When these substituents that have been given exception are included in regression they reduce the correlations considerably.

However the infrared stretching frequency $\mathrm{vC}=\mathrm{N}\left(\mathrm{cm}^{-1}\right)$ values of all the substituted $(E)-N$ benzylidene-2-amino pyrimidine compounds, have shown poor correlations $\quad(\mathrm{r}<$ 0.900 ) with the Hammett constants $\sigma, \sigma^{+} \& \sigma_{\mathrm{I}}$ and $F$ parameter. This is attributed to weak polar, inductive and field effect of the substituents to predict their electronic effects through resonance as per conjugative structure shown in Figure 1. 


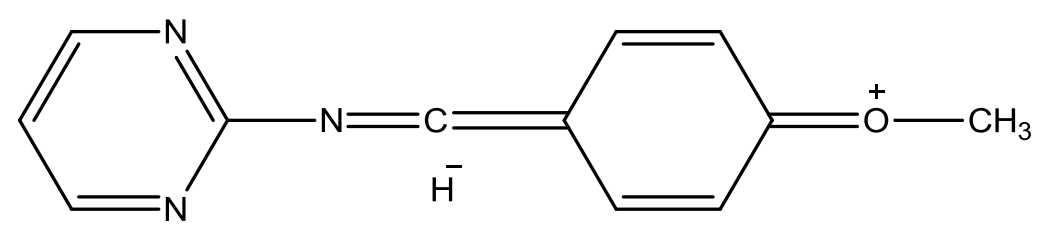

Figure 1. The resonance-conjugative structure

All the correlations have shown positive $\rho$ values. It indicates the operation of normal substituent effect with respect to infrared stretching frequency $v C=N\left(\mathrm{~cm}^{-1}\right)$ values of all the substituted $(E)$-N-benzylidene-2-amino pyrimidine compounds.

Since some of the single regression analyses, have shown poor correlations with Hammett constant and $F \& R$ parameters. It is decided to go for multi regression analysis. The multi regression analyses of the stretching frequency $v \mathrm{C}=\mathrm{N}\left(\mathrm{cm}^{-1}\right)$ values of all aryl imine compounds with inductive, resonance and Swain-Lupton's [30] parameters produce satisfactory correlations as shown in equations (5) and (6).

$$
\begin{gathered}
v \mathrm{C}=\mathrm{N}\left(\mathrm{cm}^{-1}\right)=1647.18( \pm 4.121)+9.830( \pm 1.260) \sigma_{\mathrm{I}}+12.108( \pm 2.694) \sigma_{\mathrm{R}} \\
(R=0.957, \mathrm{n}=10, \mathrm{P}>95 \%) \\
v \mathrm{C}=\mathrm{N}\left(\mathrm{cm}^{-1}\right)=1649.29( \pm 3.742)+12.719( \pm 2.715) F+11.015( \pm 1.562) R \\
(R=0.964, \mathrm{n}=10, \mathrm{P}>95 \%)
\end{gathered}
$$

\subsection{NMR spectral correlation}

The observed chemical shift values (ppm) of all the substituted $(E)$ - $N$-benzylidene-2-amino pyrimidine compounds are presented in Table 1 . These chemical shift values (ppm) are correlated with different Hammett substituent constants and $F \& R$ parameters using single and multi-linear regression analyses according to the approach of Reynolds [32,33]. In this correlation, the structureparameter equation employed is shown in equation (7).

$$
\delta=\rho \sigma+\delta_{0}
$$

where $\delta_{0}$ is the chemical shift of the corresponding parent compound.

\subsection{1 ${ }^{1} \mathrm{H}$ NMR spectral correlation:}

From the results of the statistical analyses[18, 23-29] in Table-2, it is evident that the ${ }^{1} \mathrm{H}$ NMR chemical shift $\delta \mathrm{CH}=\mathrm{N}(\mathrm{ppm})$ values of all the substituted $(E)$ - $N$-benzylidene-2-amino pyrimidine compounds except that with 4- $\mathrm{Br}, 3-\mathrm{Cl}$ and $4-\mathrm{NO}_{2}$ substituents have shown satisfactory correlations with $\sigma(\mathrm{r}=0.965), \sigma^{+}(\mathrm{r}=0.984)$ and $\sigma_{\mathrm{I}}(\mathrm{r}=0.944)$. The remaining Hammett constant $\sigma_{\mathrm{R}}$ and Swain-Lupton's $F \& R$ parameters.

The failure in correlation is due to the reason that has been stated earlier with resonance conjugative structure as shown in Figure 1. All the correlations with Hammett substituent constants $F \& R$ parameters have shown positive $\rho$ values. It indicates the operation of normal substituent effect with respect to ${ }^{1} \mathrm{H}$ NMR spectral data of all the compounds.

Some of the single regression analyses have shown poor correlations. Hence, it is decided to go for multi-regression analysis. While seeking the multi-correlation collectively the inductive, resonance and field effects[30] have shown satisfactory correlation as shown in the equations(8) and (9).

$$
\begin{gathered}
\delta \mathrm{C}=\mathrm{N}(\mathrm{ppm})=8.311( \pm 0.080)+0.219( \pm 0.016) \sigma_{\mathrm{I}}+0.376( \pm 0.021) \sigma_{\mathrm{R}} \\
(R=0.989, \mathrm{n}=10, \mathrm{P}>95 \%) \\
\delta \mathrm{C}=\mathrm{N}(\mathrm{ppm})=8.309( \pm 0.077)+0.245( \pm 0.015) \mathrm{F}+0.337( \pm 0.016) \mathrm{R} \\
(R=0.970, \mathrm{n}=10, \mathrm{P}>95 \%)
\end{gathered}
$$

\subsection{2 ${ }^{13} \mathrm{C}$ NMR spectral correlation}

The results of the statistical analyses [18, 23-29] are presented in Table 2. From Table 2, it is evident that the ${ }^{13} \mathrm{CNMR}$ chemical shift $\delta \mathrm{C}=\mathrm{N}(\mathrm{ppm})$ values of all the substituted $\mathrm{N}$-benzylidene-2-aminopyrimidine compounds except those with $3-\mathrm{Br}, 4-\mathrm{Br}$ and $3-\mathrm{NO}_{2}$ substituents have shown satisfactory correlations with Hammett constants $\sigma(\mathrm{r}=0.904)$ and $\sigma^{+}(\mathrm{r}=$ 
0.905). The remaining Hammett constants $\sigma_{\mathrm{I}}, \sigma_{\mathrm{R}}$ and Swain-Lupton's [30] $F \& R$ parameters have shown poor correlations $(\mathrm{r}<0.900)$. The failure in correlation is due to the reason that has been stated earlier with resonance conjugative structure as shown in Figure 1. All the correlations with Hammett substituent constants $F \& R$ parameters have shown negative $\rho$ values. It indicates the operation of reverse substituent effect with respect to ${ }^{13} \mathrm{C}$ NMR spectral data of all the compounds.

Some of the single regression analyses have shown poor correlations. Hence, it is decided to go for multi-regression analysis. While seeking the multi-correlation collectively the inductive, resonance and field effects[30] have shown satisfactory correlation as shown in the equations(10) and (11).

$$
\begin{gathered}
\delta \mathrm{C}=\mathrm{N}(\mathrm{ppm})=162.64( \pm 1.834)-3.834( \pm 0.013) \sigma_{\mathrm{I}}-2.570( \pm 0.135) \sigma_{\mathrm{R}} \\
(R=0.943, \mathrm{n}=10, \mathrm{P}>90 \%) \\
\delta \mathrm{C}=\mathrm{N}(\mathrm{ppm})=162.32( \pm 1.838)-3.112( \pm 0.642) \mathrm{F}-2.305( \pm 0.715) \mathrm{R} \\
(R=0.936, \mathrm{n}=10, \mathrm{P}>90 \%)
\end{gathered}
$$

\section{ANTIMICROBIAL ACTIVITIES}

\subsection{Antibacterial sensitivity assay}

The antibacterial activities of all synthesized substituted (E)- $N$-benzylidene-2aminopyrimidine compounds have been studied against three gram positive pathogenic strains $B$. substilis, $M$. lutes, $S$. aureus and two gram negative strains $E$. coli and $P$. aeruginosa. The disc diffusion technique has been followed using the Kirby-Bauer method [34], at a concentration of $250 \mu \mathrm{g} / \mathrm{mL}$ and ciprofloxacin was used as standard. The antibacterial screening effect of prepared substituted (E)- $N$-benzylidene-2-aminopyrimidine compounds is shown in Figure 2 (Plates 1-10). The measured zone of inhibition values are given in Table $\mathbf{3}$ and the corresponding clustered column chart is shown in Figure 3. Zone of inhibition $(\mathrm{mm})$ values of antibacterial activity of substituted $(E)$ - $N$-benzylidene-2-aminopyrimidine compounds reveals that all the compounds have shown moderate to good activity against all the five microorganisms evaluated in the present investigation. The 3-Cl and 4- $\mathrm{CH}_{3}$ substituted Schiff's bases have shown good activity against B.subtilis. The 4-Br substituted compound has shown good activity against M.luteus and S.aureus. The 4-F substituted compound has shown good activity against P.aeruginosa and the remaining compounds have shown moderate activity. 


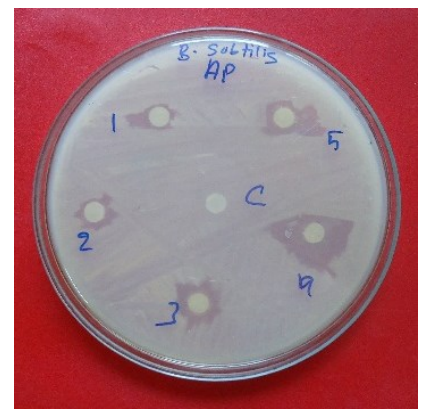

Plate-1

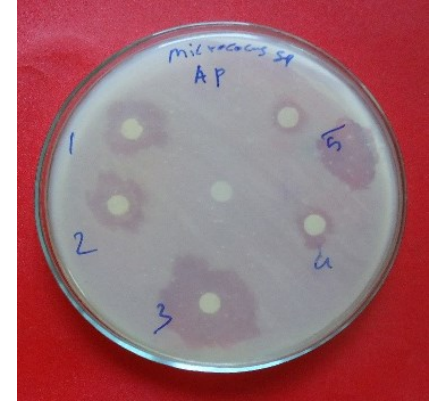

Plate-3

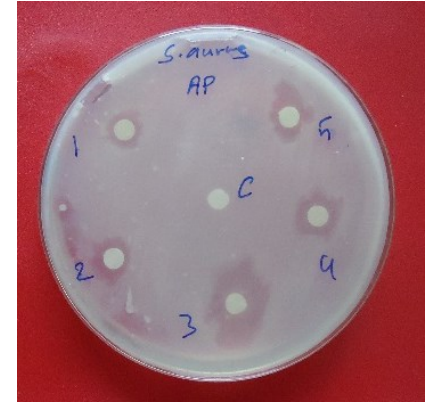

Plate-5

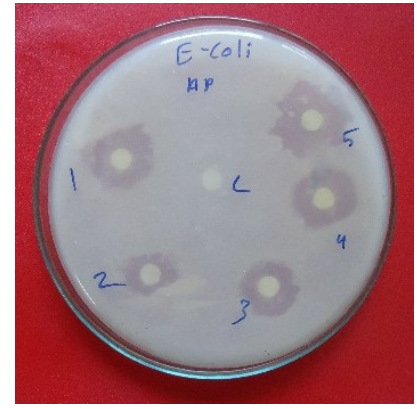

Plate-7

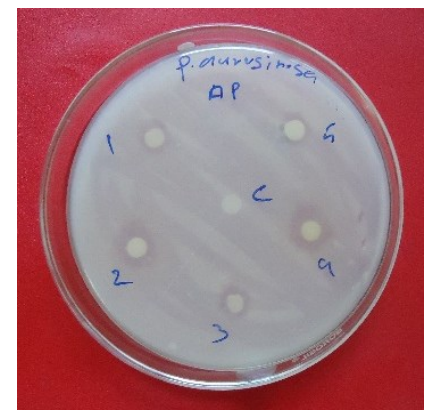

Plate-9

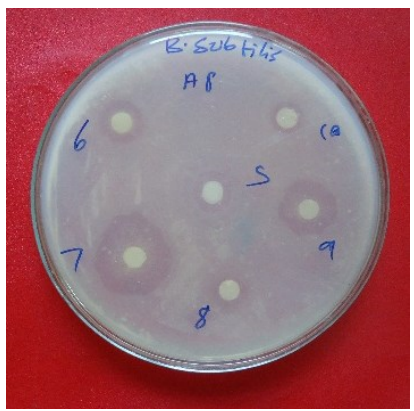

Plate-2

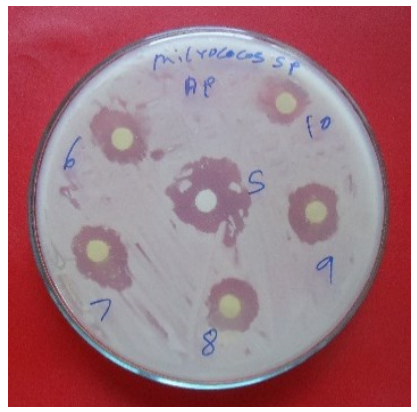

Plate-4

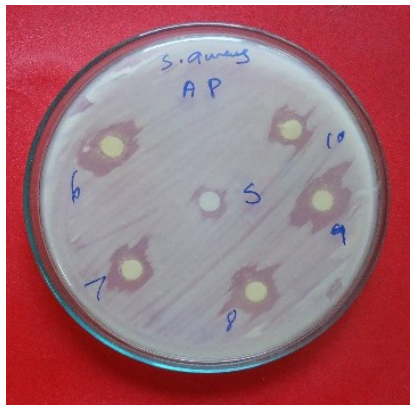

Plate-6

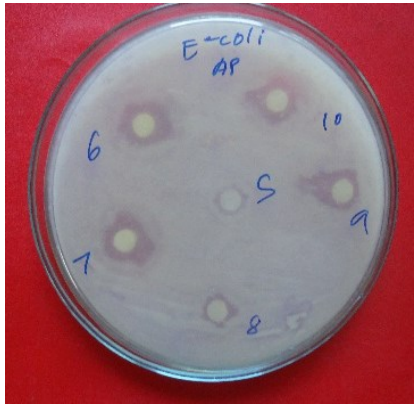

Plate-8

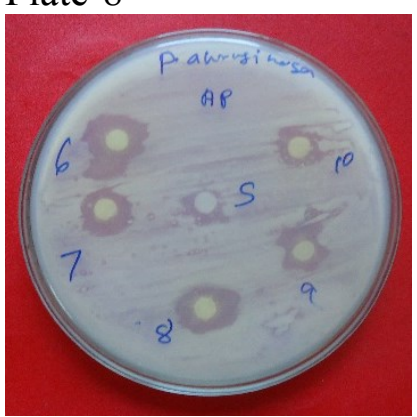

Plate-10

Figure 2. Antibacterial activity of substituted $(E)$ - $N$-benzylidene-2-aminopyrimidines (petri-plates) 
Table 3. Zone of inhibition $(\mathrm{mm})$ values of antibacterial activity of substituted $(E)$ - $N$-benzylidene-2-aminopyrimidines.

\begin{tabular}{|l|l|l|l|l|l|l|}
\hline \multirow{2}{*}{ S.No. } & \multirow{2}{*}{ Substituents } & \multicolumn{3}{|l|}{ Zone of inhibition(mm) } \\
\cline { 3 - 7 } & & Gram positive Bacteria & \multicolumn{3}{l|}{ Gram negative Bacteria } \\
\cline { 3 - 7 } & & B.subtilis & M.luteus & S.aureus & E. coli & P. aeruginosa \\
\hline 1 & $\mathrm{H}$ & 7 & 10 & 7 & 10 & 7 \\
\hline 2 & $3-\mathrm{Br}$ & 7 & 9 & 8 & 8 & 9 \\
\hline 3 & $4-\mathrm{Br}$ & 9 & 14 & 12 & 9 & 7 \\
\hline 4 & $3-\mathrm{Cl}$ & 12 & 7 & 9 & 10 & 10 \\
\hline 5 & $4-\mathrm{Cl}$ & 8 & 7 & 9 & 11 & 7 \\
\hline 6 & $4-\mathrm{F}$ & 8 & 9 & 10 & 8 & 12 \\
\hline 7 & $4-\mathrm{CH}_{3}$ & 13 & 10 & 9 & 8 & 9 \\
\hline 8 & $4-\mathrm{OCH}_{3}$ & 7 & 9 & 10 & 7 & 10 \\
\hline 9 & $3-\mathrm{NO}_{2}$ & 10 & 10 & 12 & 7 & 9 \\
\hline 10 & $4-\mathrm{NO}_{2}$ & 7 & 8 & 9 & 7 & 8 \\
\hline Standard & $\mathrm{Ciprofloxacin}$ & 13 & 14 & 10 & 12 & 12 \\
\hline Control & $\mathrm{DMSO}$ & 0 & 0 & 0 & 0 & 0 \\
\hline
\end{tabular}

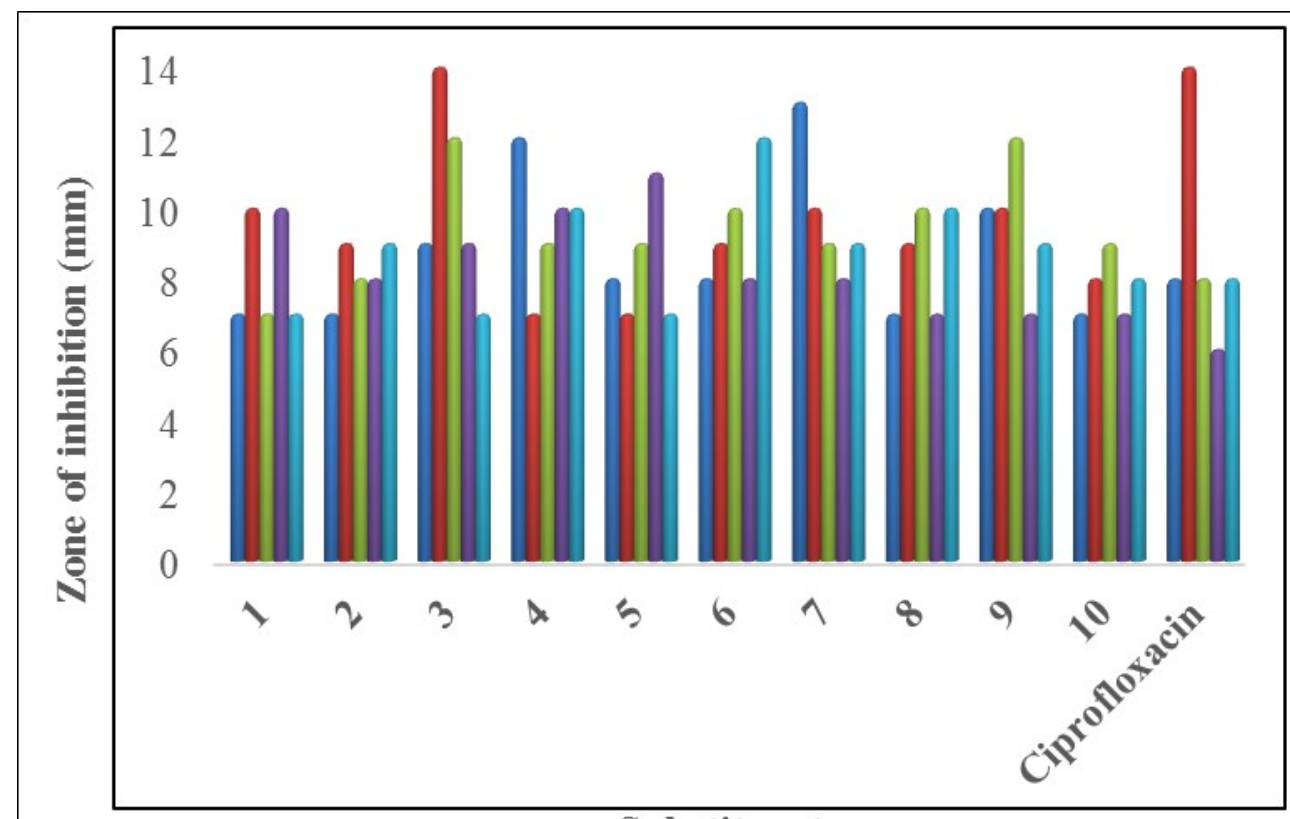

Substituents
1. $\mathrm{H}$

2. $3-\mathrm{Br}$

3. $4-\mathrm{Br}$

4. $3-\mathrm{Cl}$

5. $4-\mathrm{Cl}$

6. $4-\mathrm{F}$

7. $4-\mathrm{CH}_{3}$

8. $4-\mathrm{OCH}_{3}$

9. $3-\mathrm{NO}_{2}$

10. $4-\mathrm{NO}_{2}$

\section{Bacillus}

- M. luteus

$\square$ S. aureus

E. coli

$\square$ P. aurogenosa

Figure 3. Antibacterial activity of substituted $(E)-N$-benzylidene-2-aminopyrimidines (clustered column chart)

\subsection{Antifungal sensitivity assay}

The antifungal activities of all synthesized substituted (E)- $N$-benzylidene-2aminopyrimidine compounds have been studied against three fungal species namely $A$. niger, $M$. species and T. species. The The disc diffusion technique has been followed using the Kirby-Bauer method [34], at a concentration of $250 \mu \mathrm{g} / \mathrm{mL}$ and Ciprofloxacin was used as standard. The antifungal screening effect of prepared substituted (E)- $N$-benzylidene-2-aminopyrimidine compounds is shown in Figure 4. (Plates 1-4). The measured zone of inhibition values are given in Table 4 and the corresponding Clustered column chart is shown in Figure 5. All the compounds have shown moderate to good activity against all the three fungal species evaluated in general. The 4- $\mathrm{Cl}, 4-\mathrm{Br}, 4-\mathrm{CH}_{3}, 4-\mathrm{OCH}_{3}$ and $4-\mathrm{NO}_{2}$ substituted compounds have shown good activity against 
A.niger. The parent compound $(\mathrm{H})$ and $3-\mathrm{Br}$ substituted compounds have shown good activity against $M$. species. The 4-Br substituted compound has also shown good activity against T.viride.

Table 4. Zone of inhibition ( $\mathrm{mm}$ ) values of antifungal activities of substituted (E)-N-benzylidene-2-aminopyrimidines

\begin{tabular}{|l|l|l|l|l|}
\hline \multirow{2}{*}{ Entry } & \multirow{2}{*}{ Substituents } & \multicolumn{4}{l|}{ Zone of inhibition $(\mathrm{mm})$} \\
\cline { 3 - 5 } & & A. niger & M. species & T. viride \\
\hline 1 & $\mathrm{H}$ & 9 & 13 & 10 \\
\hline 2 & $3-\mathrm{Br}$ & 9 & 15 & 11 \\
\hline 3 & $4-\mathrm{Br}$ & 10 & 10 & 13 \\
\hline 4 & $3-\mathrm{Cl}$ & 11 & 10 & 12 \\
\hline 5 & $4-\mathrm{Cl}$ & 10 & 11 & 11 \\
\hline 6 & $4-\mathrm{F}$ & 10 & 13 & 10 \\
\hline 7 & $4-\mathrm{CH}_{3}$ & 11 & 8 & 9 \\
\hline 8 & $4-\mathrm{OCH}_{3}$ & 11 & 10 & 12 \\
\hline 9 & $3-\mathrm{NO}_{2}$ & 9 & 12 & 10 \\
\hline 10 & $4-\mathrm{NO}_{2}$ & 10 & 9 & 11 \\
\hline Standard & $\mathrm{Ciprofloxacin}$ & 10 & 15 & 14 \\
\hline Control & DMSO & 0 & 0 & 0 \\
\hline
\end{tabular}

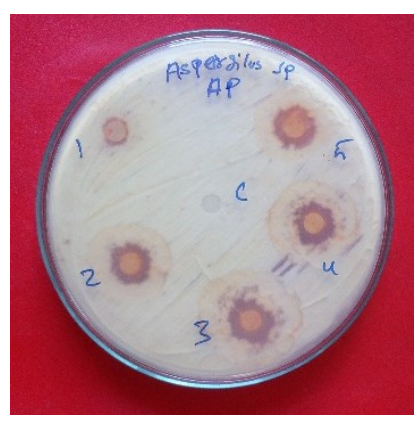

Plate-1

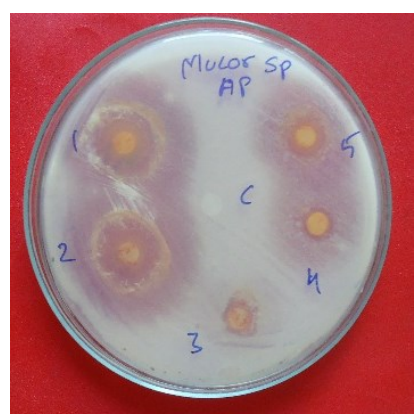

Plate-3

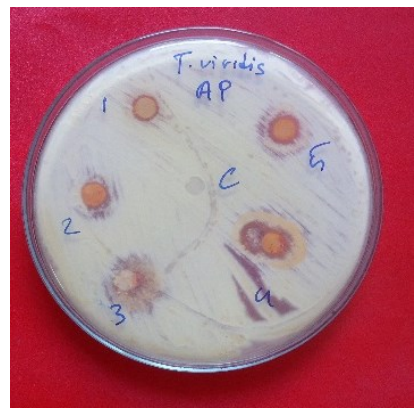

Plate-5

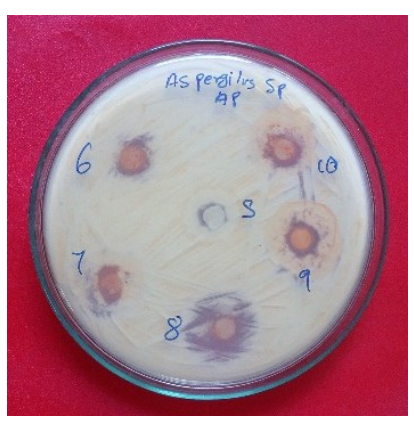

Plate-2

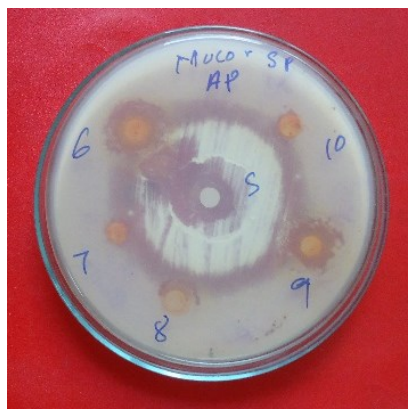

Plate-4

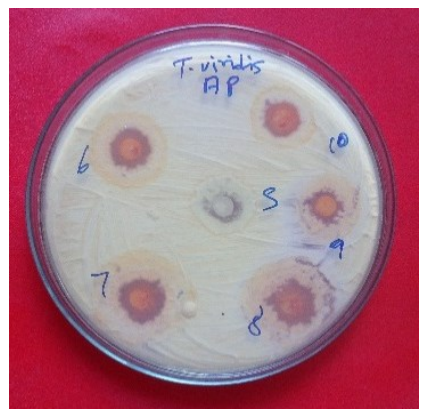

Plate-6

Figure 4. Antifungal activity of substituted (E)- $N$-benzylidene-2-aminopyrimidines (petri-plates) 


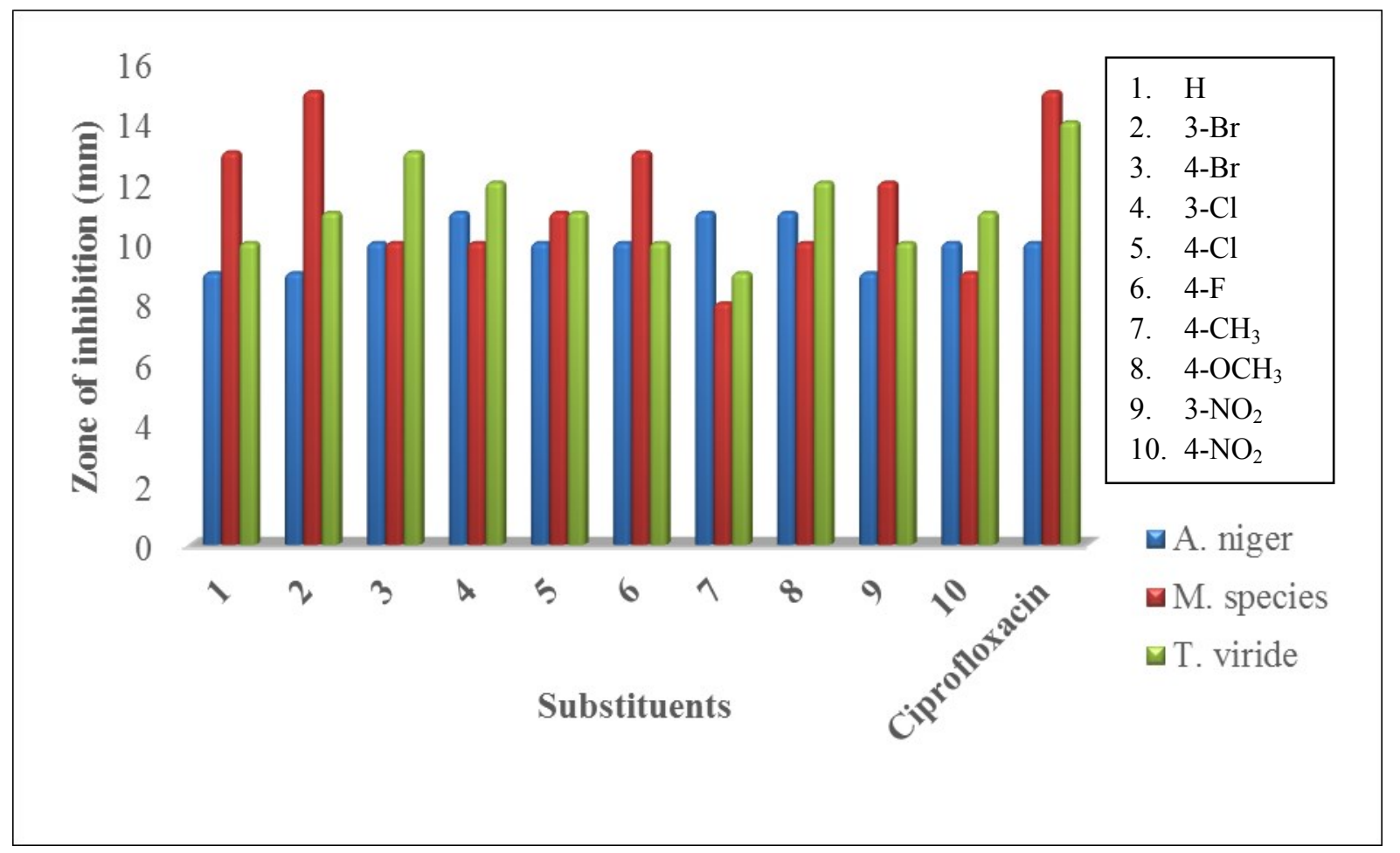

Figure 5. Antifungal activity of substituted $(E)$ - $N$-benzylidene-2-aminopyrimidines (clustered column chart)

\section{CONCLUSIONS}

A series of substituted (E)- $N$-benzylidene-2-aminopyrimidine compounds have been synthesized by condensation method. These compounds were confirmed by their physical constants and spectral data. The spectral data of these compounds have been correlated with Hammett sigma constants and $F \& R$ parameters using single and multi-linear regression analysis. Most of the single linear regression analyses have been satisfactory correlations for all the substituents with UV, IR and NMR spectral data. Some of the compounds have been shown good antibacterial and antifungal activities. Most of the compounds have been shown moderate activity.

\section{Acknowledgement}

The authors thank DST NMR Facility, Department of Chemistry, Annamalai University, Annamalainagar-608 002, for recording NMR spectra of all compounds.

\section{References}

[1] Deeb A, Bayoumy B. E, El-Mobayed M, Egypt. J. Pharm. Sci., 27 (1986) 37-41.

[2] Schiff's H, Ann. Chem., 3 (1864) 343.

[3] Rana A. K, Shah J. R, Ind. Chem. Res., 21 (1982) 177.

[4] Cohen M. D, Schmidt G. M. J, Flavian S. F, J. Chem Soc., (1964).2041-2051.

[5] Rana A. K, Shah J. R, J. Ind. Chem. Soc., 58 (1981) 1100.

[6] Bahar A. W, Shulgin A. I, J. Am. Chem. Soc., 80 (1959)1523.

[7] Layer R. W, Chem. Rev., 63 (1963) 489-499.

[8] Correa WH, Papadopoulos C, Radnidge P, Roberts BA, Scott JL, Green Chem., 4 (2002) 245-251.

[9] Naeimi H, Safari J, Heidarnezhad A, Dyes Pigments, 73 (2007) 251-253.

[10] Sasaki C, Nakajima K, Kojima M, Bull Chem. Soc. Jpn., 64 (1991) 1318-1324. 
[11] Casella L, Ibers JA, Inorg. Chem., 20 (1981) 2438-2448.

[12] Al zoubi W, Kandil F, Khaled Chebani M, Spectrochim Acta., 79A (2011) 1909-1914.

[13] Waldemar A, Rainer RS, Am. Chem. Soc., 120 (1998) 708-714.

[14] Schmeyers J, Toda F, Boy J, Kaupp G, J. Chem. Soc. Perkin Trans., 2 (1998) 989-994.

[15] Tanaka K, (2003) Solvent-free Organic Synthesis; Wiley-VCH: Weinheim.

[16] Sans D, Perona A, Claramunt RM, Elquero J, Tetrahedron, 61 (2005) 145-154.

[17] Fernandez-G JM, Del Rio-Portilla F, J. Mol. Str., 561 (2001) 197-207.

[18] Sakthinathan S. P., Suresh R., Mala V., Sathiyamoorthi K., Kamalakkannan D., Ranganathan K., John Joseph S., Vanangamudi G., Thirunarayanan G., Int. J. Sci. Res. Know., 1(11) (2013) 472-483.

[19] Issa Y. M., El Ansary A. L., Sherif O. E., Hassib H. B., Spectrochim Acta, 79A (2011) 513521.

[20] Goerdeler, Joachim, Chemische Berichte, 96 (1963) 1630-1642.

[21] El-Masry, Afaf. H., Pak. J. Sci. Ind. Res., 45(2) (2002) 69-75.

[22] Shorter. J, Correlation analysis in Chemistry: an introduction to linear free energy relationships, Clarendon press, London, (1973).

[23] G. W. Snedecor and W. G. Cochran, Statistical Methods, Lowa state University Press, Ames, Iowa, (1967).

[24] Sakthinathan S. P., Suresh R., Mala V., Sathiyamoorthi K., Kamalakkannan D., Ranganathan K., Arulkumaran R., Vijayakumar S., Sundararajan R., Vanangamudi G., Thirunarayanan G., Int. Let. Chem. Phy. Ast., 6 (2013) 77.

[25] Suresh R., Kamalakkannan D., Ranganathan K., Arulkumaran R., Sundararajan R., Sakthinathan S. P., Vijayakumar S., Sathiyamoorthi K., Mala V., Vanangamudi G., Thirumurthy K., Mayavel P., Thirunarayanan G., Spectrochim. Acta, 101A (2013) 239-248.

[26] Thirunarayanan G., Sekar K. G., J. Taibah Univ. Sci., 8 (2014) 124-136

[27] Senbagam R., Rajarajan M., Vijayakumar R., Manikandan V., Balaji S., Vanangamudi G., Thirunarayanan G., World Scientific News, 3 (2015) 155-171.

[28] Vijayakumar R., Rajarajan M., Balaji S., Manikandan V., Senbagam R., Vanangamudi G., Thirunarayanan G., World Scientific News, 3 (2015) 81-98.

[29] Rajarajan M., Senbagam R., Vijayakumar R., Manikandan V., Balaji S., Vanangamudi G., Thirunarayanan G., World Scientific News, 3 (2015) 155-171.

[30] Swain C. G., Lupton E. C., J. Am. Chem. Soc., 90 (1968) 4328-4337.

[31] a) Jaffe H. H., Chem. Rev., 53(2), (1953), 191-261.

b) Jaffe H. H., J. Am. Chem. Soc., 76(22) (1954), 5843-5846.

[32] G. K. Hamer, I. R. Peat, W. F. Reynolds, Can. J. Chem., 51(6), (1973), 897-914.

[33] D. A. Dawson, G. K. Hamer, W. F. Reynolds, Can. J. Chem., 52(1), (1974), 39-45.

[34] Bauer A. W., Kirby W. M. M., Sherris J. C., Truck M., Am. J. Clinical Pathology, 45 (1966) 493-498. 